\title{
A comparison study of Morven gold and Tander virginia cigarettes with respect to its spasmogenic, spasmolytic and chemical screening
}

\author{
Naveed Ullah ${ }^{1 \star}$, Mir Azam Khan ${ }^{1}$, Afzal Haq Asif ${ }^{2}$, Habib Ahmad $^{3}$, Taimur Khan ${ }^{4}$, Taous Khan ${ }^{5}$ \\ and Waqar Ahmad ${ }^{1}$
}

\author{
${ }^{1}$ Department of Pharmacy, University of Malakand, Chakdara Pakistan. \\ ${ }^{2}$ Department of Pharmacology, Frontier Medical College, Abbottabad Pakistan. \\ ${ }^{3}$ Department of Genetics, Hazara University, Mansehra Pakistan. \\ ${ }^{4}$ Department of Psychiatry, Lady Reading Hospital Peshawar, Pakistan \\ ${ }^{5}$ Department of Pharmacy, Comsats Institute of Information \& Technology, Abbottabad, Pakistan
}

Accepted 17 March, 2011

\begin{abstract}
The ethanolic extracts derived from cigarettes (Morven gold and Tander virginia) were screened for chemicals, spasmogenic and spasmolytic activities. M. gold extract showed a strong relaxant activity that is $70 \%$ against $\mathrm{KCl}$ induced contractions while $T$. virginia was found to have a mild spasmolytic activity of $(06 \%)$. Furthermore, a moderate spasmogenic effect of $M$. gold had being measured, while no measurable spasmogenic activity has been shown by the $T$. virginia. It can be concluded from the current study that Morven gold has a strong spamsmogenic and spasmolytic activity, while the Tander is not found to be so efficient in either case. The chemicals found in sufficient quantity in both the extracts were tannins, saponin and glycosides. Minute quantity of carbohydrates were also been noted in M. gold. The presence of alkaloids were also been noted in excess quantity in $T$. virginia and less amount in M. gold. Further studies are necessary to elucidate its exact mechanism of action.
\end{abstract}

Key words: Spasmogenic, spasmolytic, chemical screening, Morven gold, Tander virginia.

\section{INTRODUCTION}

Cigarette is a type of smoking tobacco produced and used in all over the world. It is a small roll of paper mostly about $7 \mathrm{~cm}$ of length and 5 to $7 \mathrm{~mm}$ of width, filled with a finely, pieced tobacco leaves and may some additives. With one end of the cigarette a filter is attached, mostly made up of cellulose acetate and of about $2 \mathrm{~cm}$ of length. Morven gold and Tander virginia are the types cigarette, $M$. gold which is prepared in Pakistan by Lakson Tobacco Company Limited while $T$. virginia is prepared by imperial cigarette industries (Pvt) Ltd. M. gold is believed to be a very good quality cigarette and is expensive while the $T$. virginia is believed to be so strong which is not so easy for every one to tolerate and it is so cheaper then $M$. gold. Presently the use of tobacco is the leading cause of

${ }^{*}$ Corresponding author. E-mail: naveedjia@yahoo.com. Tel: 0092-3455910522. death worldwide (Brundtland, 2000) and is estimated that by 2030 it would be over 10 million annual deaths globally (Warnakulasuriya et al., 2005; John, 2005), 70\% of which will be in the developing world (WHO, 2000). It has also been reported that all forms of tobacco carry serious health consequences, most importantly is oral and pharyngeal cancers (Gupta and Ray, 2003; Mack, 2001; IARC, 1985; Merchant et al., 2000; Avon, 2004). In Pakistan oral cancer is the second most common cancer in women and third most common in men (Jafarey and Zaidi, 1987). Smoking (in form of cigarette) of tobacco has also been reported a well- known cause of oral sqamous cell carcinoma (Gupta et al.,1982; Jayant and Deo, 1986; Brennan et al., 1995; Choi and Kahyo, 1991; Negri et al.,1993). Smoking during pregnancy may cause low-birth weight, pre-mature birth and infant death (U.S. Dept. of Health and Human Services, 2001), and also increase the neonatal health care costs (Adams et al., 2002). Further more, cigarettes contain carcinogens that 
not only stimulate genetic damage, but also result the production of atypical cells, mutations and eventually cancer, they also impair the function of the p53 gene which, when functioning normally, prevents mutations from developing into cancer (Langdon and Partridge, 1992). It has also been reported that cigarette smoke contains carcinogens that alter biochemical defense systems that lead to deleterious effects on the respiratory tract, heart, pancreas, reproductive tract and other organs (Ostergaard, 1977), and also has a link to common causes of death and disability in elderly aged persons associated with chronic illnesses (Bratzler et al., 2002). But smoking has also been observed to reduce the incidence of various diseases tendometrial cancer, ulcerative colitis, hypertension in pregnancy, Alzheimer's disease and Parkinson disease (English et al., 1995; Graves et al., 1991; Van Duijin and Hofman, 1991). Several other epidemiological studies have also found a beneficial effect of smoking in Parkinson disease (Fratiglioni and Wang, 2000; Checkoway et al., 2002).

In the current study, we present a comparison between $M$. gold and $T$. virginia with respect to its spasmogenic, spasmolytic and chemical screening. This study was designed with a view to confirm and explore the pharmacological and chemical screening of two types of cigarettes and a comparison between the two, which contains tobacco and other ingredients of different quality.

\section{MATERIALS AND METHODS}

\section{Sample material}

M. gold and T. virginia cigarettes purchased from local market Abbottabad Pakistan. Sample pack, marked with a number 1378 and 1379 has been deposited in Pharmacy Museum, University of Malakand Pakistan.

\section{Preparation of extracts}

The materials were withdrawn from each type of cigarette and were pulverized into fine powder and weighed $15 \mathrm{~g}$ for either case. Each was then extracted in $70 \%$ ethanol. Both the extracts were separately filtered and evaporated under reduced pressure to yield a gum ( 1.5 to $02 \mathrm{~g}$ for each) by using rotary evaporator.

\section{Drugs and standards}

Analytical grade chemicals were used in the bioassay technique and chemical screening. All the solutions were freshly prepared in distilled water on the same day of experiments.

\section{Animals and data recording}

Rabbits of either sex were breed locally. Their average weight was in the range of 1.5 to $2.0 \mathrm{~kg}$. They were maintained at the "Animal House of Frontier Medical College Abbottabad" as per Byelaws of Scientific Procedures. Animals were given free access to standard diet along with fresh water. Before the start of experiments, animals were given only water and were kept fasted overnight. Intestinal responses were recorded using organ bath and kymograph.

\section{Spasmogenic activity}

The extracts were screened for possible cholinomimetic and spasmolytic activities as per procedure mentioned. Tyrode's solution was prepared having the following concentration $(\mathrm{mM}): \mathrm{KCl}$ 2.68, $\mathrm{NaCl}$ 136.9, $\mathrm{MgCl}_{2}$ 1.05, $\mathrm{NaHCO}_{3}$ 11.90, $\mathrm{NaH}_{2} \mathrm{PO}_{4}$ 0.42, $\mathrm{CaCl}_{2} 1.8$ and glucose 5.55. The animals were then slaughtered and their abdomens were opened. Rabbit's jejunum portion(s), of about 1.5 to $2 \mathrm{~cm}$ length, was isolated and mounted in the tissue bath containing $10 \mathrm{ml}$ of Tyrode's solution maintained at $37^{\circ} \mathrm{C}$ and supplied with carbogen gas $(5 \%$ carbon dioxide and oxygen mixture). These portion(s) were kept in Tyrode's solution previously aerated with the carbogen gas (Qayum, 2004). Earlier, the tissues were stabilized for normal activity for a period of about 25 to $40 \mathrm{~min}$. For possible pharmacological screening on the tissues through series of experiments, ethanolic extracts of $M$. gold and $T$. virginia were tried at doses of 02 and $05 \mathrm{mg} / \mathrm{ml}$. All the doses were applied in cumulative manner and the results were recorded (Farre et al., 1991). The spasmogenic and spasmolytic activity was recorded as given in Figure 1.

\section{Spasmolytic activity}

We used the procedure described by Farre et al. (1991), to screen spasmolytic activity. Contractions in the intestine portions were produced by high $\mathrm{KCl}(80 \mathrm{mM})$ to depolarize the intestine portions (Farre et al., 1991). The extracts were then applied in the similar fashion to relax the tissues and percentage relaxation response on $\mathrm{KCl}$ induced contractions was recorded as given in Table 1, and shown in Figure 1. The following formula was used for calculations:

$\%$ Inhibition/stimulation =

$100-\frac{\text { Averageheight of contractions after extract }(\mathrm{mm})}{\text { Averageheight of normal contraction }(\mathrm{mm})} \times 100$

\section{Chemical screening}

The ethanolic extract of both type of cigarettes were evaluated for the presence of alkaloids, glycosides, terpenes, saponins, tannins, flavonoids and carbohydrates using simple qualitative methods of Sofowora (1993) and Evans (1998). Also the $\mathrm{pH}$ of both the extracts was recorded.

\section{RESULTS AND DISCUSSION}

Moderate spasmogenic activity of ethanolic extract of $M$. gold had been noted while $T$. virginia extract did not show any spasmogenic effect as shown in Figure 1. By this it can be concluded that, the cholinomimetic activity of ethanolic extract of Morven, may be because of the presence of nicotine which may act on any mechanism as discussed. According to Gillespie and Mackenna (1960), the response to nicotine of intestinal preparations in vitro is usually a contraction due to stimulation of the parasympathetic cholinergic neurons in Auerbach's plexus. Same results were recorded in current study for 


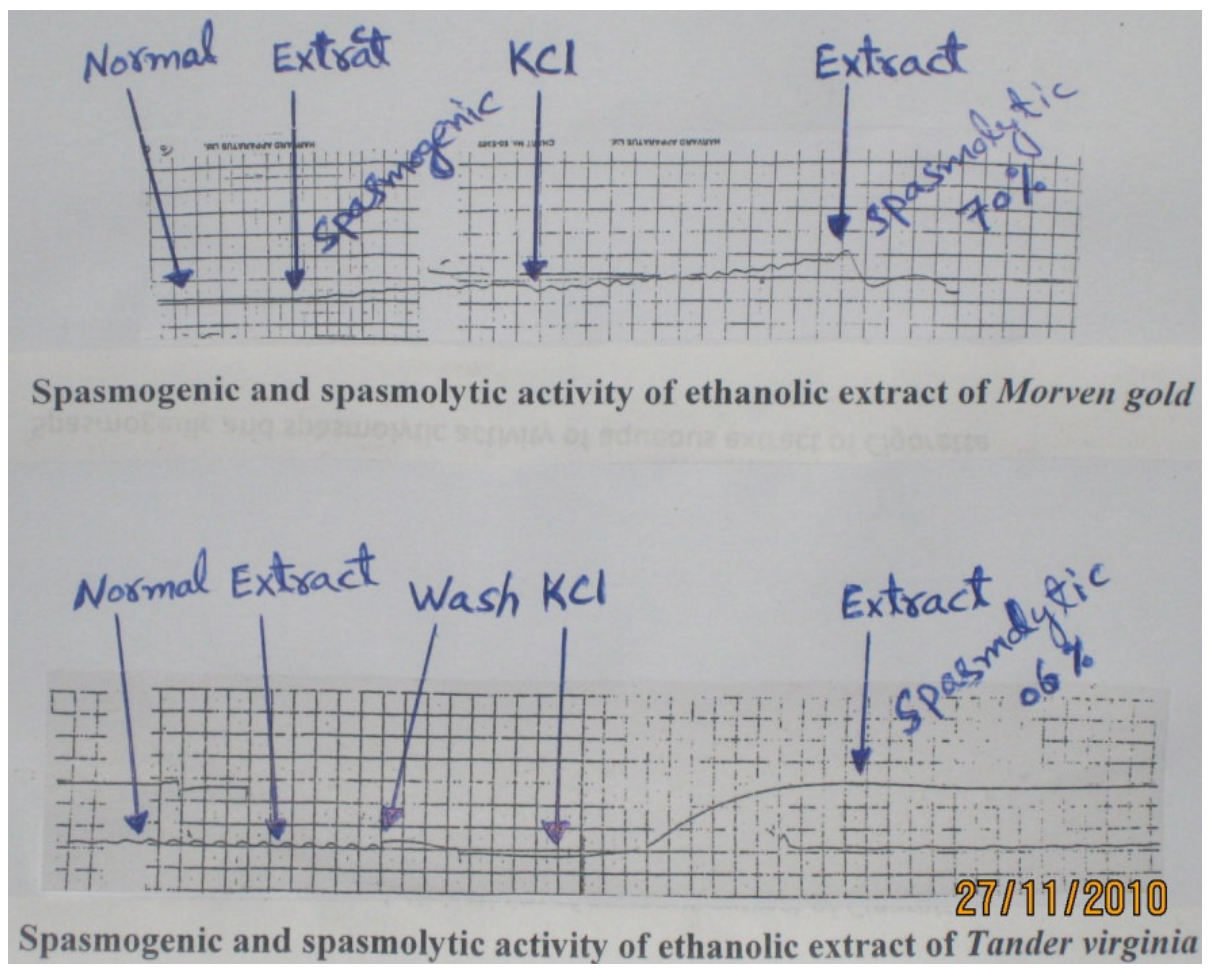

Figure 1. Spasmogenic and spasmolytic activity of M.gold and T. viginia In the first portion of the graph, $M$. gold showed a good spasmogenic and spasmolytic activity, while in the second portion $T$. virginia showed a mild spasmolytic activity and did not show any significant spasmogenic activity.

Table 1. Spasmogenic and spasmolytic activity of ethanolic extract of M. gold and T. virginia cigarettes.

\begin{tabular}{lccc}
\hline Extract & Spasmogenic activity & Spasmolytic activity (\%) & Nature \\
\hline M. gold & Moderate & 70 & Acidic \\
T. virginia & Negative & 06 & Acidic \\
\hline
\end{tabular}

M. gold was found to be more effective both for spasmogenic and spasmolytic activity, while the $T$. virginia was noted to be a moderate effectiveness for spasmolytic activity.

Morven. Also, the nature of the medium had been studied, which was found to be acidic in both the extracts.

In another series of experiments, the tissues were depolarized with high potassium level $(80 \mathrm{mM}$ bath concentration) that produced a sustained contraction (Farre et al., 1991). The test samples were then tried in cumulative manner to observe the spasmolytic effect on the tissues. As it has been postulated that contractions produced by potassium are mediated through calcium channels through influx of calcium from extra cellular fluid and a substance which will inhibit the contraction produced by $\mathrm{KCl}$ is considered to have calcium channel blockade (Bolton, 1979). According to Figure 1, both the extracts produced a spasmolytic effect on the $\mathrm{KCl}$ depolarized tissues in dose dependant manner; with a maximum dose of $5.0 \mathrm{mg} / \mathrm{ml} \mathrm{KCl}$-induced contractions
( $80 \mathrm{mM}$ ) were relaxed by the extract in the similar doses. As in the current study the ethanolic extract of Morven was found to have strong spasmolytic effect, noted as $70 \%$, and for Tander it was measured as $06 \%$ given in Table 1, and shown in Figure 1. Positive relaxing effects on $\mathrm{KCl}$ induced contraction are mostly referred to calcium channel blocking activity (Gilani et al., 2005). Hence, the spasmolytic activity of extracts may be mediated through calcium channel blocking activity. On other point of view, Ambache (1946) and Felberg (1951) obtained evidence that barium could excite ganglion cells in the intestine for spasmogenic effect and Ambache (1949) showed that barium excited ganglion cells. Douglas et al. (1961) reported that the spasmogenic effect of barium in the intestine or superior cervical ganglion was depressed by hexamethonium or nicotine. So, from these aforementioned 
Table 2. Chemical screening of $M$. gold and $T$. virginia cigarettes.

\begin{tabular}{|c|c|c|c|}
\hline \multirow{2}{*}{ Test } & \multirow{2}{*}{ Observation } & \multicolumn{2}{|c|}{ Inferences } \\
\hline & & Morven Ext & Tander Ext \\
\hline Alkaloids : Extract $+10 \%$ tannic acid solution & Turbidity/precipitation & + & +++ \\
\hline Saponin: Extract vigorously shaken in a test tube for 2 minutes. & Frothing less than $1 \mathrm{~cm}$ & ++ & ++ \\
\hline $\begin{array}{l}\text { Flavonoids: (Shinoda test) Ethanolic extract + magnesium fillings + } \\
\text { conc } \mathrm{HCl}\end{array}$ & Pink or red color & - & - \\
\hline Tannins: Extract + Few drops of $\mathrm{FeCl}_{3}$ & $\begin{array}{l}\text { An immediate green } \\
\text { precipitate formed }\end{array}$ & +++ & +++ \\
\hline $\begin{array}{l}\text { Terpenes: Decolorized Extract residue + Chloroform + acetic } \\
\text { anhydride + conc. } \mathrm{H}_{2} \mathrm{SO}_{4}\end{array}$ & Brown precipitate formed & - & - \\
\hline Carbohydrates: Extract + Molisch's reagent + conc. $\mathrm{H}_{2} \mathrm{SO}_{4}$ & Purple precipitate & + & - \\
\hline Glycosides: Extract + Fehlings reagent \& boiled for 2 min & Brick red color & ++ & ++ \\
\hline
\end{tabular}

+ Mild (present), ++ moderate (present), +++ excess (present), -absent.

discussed mechanisms, may be one would be responsible for the spasmolytic effect of these extracts. Further studies are necessary to elucidate its exact mechanism of action. The qualitative chemical screening of cigarette revealed the presence of tannins, saponin and glycosides. Alkaloids were found in trace amount in Tander, while in less quantity in Morven. A minute quantity of carbohydrates has also been noted in case of Morven as given in Table 2.

\section{Conclusion}

In the current study a moderate spasmogenic activity of ethanolic extract of $M$. gold cigarette have been found. It was also noted that both the extract have a relaxant activity against $\mathrm{KCl}$ induced intestinal contraction, which may be due to any of above discussed mechanism. The spasmolytic activity of the ethanolic extract of Morven was found to be more efficient then the spasmolytic activity caused by ethanolic extract of Tander against $\mathrm{KCl}$ induced contraction. Further studies are necessary to elucidate its proper mechanism of action. The results also showed the acidic nature of the extracts and the presence of alkaloids, tannins, saponin and glycosides, as given in Table 2.

\section{ACKNOWLEDGEMENTS}

Higher Education Commission, Government of Pakistan is acknowledged for its financial support. We are deeply indebted to Dr. A J Khan, Principal, Frontier Medical College for their Laboratory support and all other participants of this study who gave us their time, especially lbrar Hussain and Muhammad Zahid Laboratory Assistants, Frontier Medical College Abbottabad Pakistan.

\section{REFERENCES}

Adams EK, Miller VP, Ernst C, Nishimura BK, Melvin C, Merritt R (2002). Neonatal Health care costs related to smoking during pregnancy. Health Econ., 11: 193-206.

Ambache N (1946). Interaction of drugs and the effect of cooling on the isolated mammalian intestine. J. Phy. Biol., 104: 266-287.

Ambache N (1949). The nicotinic action of substances supposed to be purely smooth-muscle stimulating. (B) Effect of $\mathrm{BaCl} 2$ and pilocarpine on the superior cervical ganglion J. Physiol., 110: 164-172.

Avon SL (2004). Oral Mucosal Lesions Associated with Use of Quid. J. Can. Dent. Assoc., 70: 244-8.

Bolton TB (1979). Mechanism of action of transmitters and other substances on smooth muscles. Physiol., 59: 606-718.

Bratzler DW, Oenhlert WH, Austell A (2002). Smoking in the elderly- it's never too late to quit. J. Okla. State Med. Assoc., 95: 185-91.

Brundtland GH (2000). Achieving worldwide tobacco control. JAMA, 284: 750-751.

Checkoway H, Powers K, Smith-Weller T, Franklin GM, Longstreth WTJr, Swanson PD (2002). Parkinson's disease risks associated with cigarette smoking, alcohol consumption and caffeine intake. Am. J. Epidemiol., 155: 732-38.

Choi SY, Kahyo H (1991). Effect of cigarette smoking and alcohol consumption in the aetiology of cancer of the oral cavity, pharynx and larynx. Int. J. Epidemiol., 20: 878-885.

Douglas WW, Lywood DW, Straub RW (1961). The stimulant effect of Barium on the release of Acetylcholine from the Superior cervical ganglion. J. Physiol., 156: 515-522.

English DR, Holman CDJ, Milne E, Winter MG, Hulse GK, Codde JP, Bower Cl, Corti B, de Klerk N, Knuiman MW, Kurinczuk JJ, Lewin GF, Ryan GA (1995). The quantification of drug caused morbidity and mortality in Australia, 1995 edition. Canberra: Commonwealth Department of Human Services and Health.

Evans WC (1998). Trease and Evans Pharmacognose $14^{\text {th }}$ Edition W.B. Saunders Company Limited, pp. 315-316. 
Farre AJ, Columbo M, Fort M, Gutierrez B (1991). Differential effects of various $\mathrm{Ca}++$ antagonists, Gen. Pharmacol., 22: 177-181.

Feldberg W (1951). Effects of ganglion blocking substances on the small intestine. J. Physiol., 112: 177-196.

Fratiglioni L, Wang HX (2000). Smoking and Parkinson's and Alzheimer's disease: Review of the epidemiological studies. Behav. Brain Res., 113: 117-20.

Gilani AH, Bukhari IA, Khan RA, Arif-ullah K, Farman U, Viqar UA (2005). Cholinomimetic and Calcium Channel Blocking Activities of Carthamus oxycantha. Phytother. Res., 19: 679-683.

Gillespie JS, Mackenna BR (1960). The inhibitory action of nicotine on the rabbit colon J. Physiol., 152: 191-205.

Graves AB, Van Duijn CM, Chandra V, Fratiglioni L, Heyman A, John AF, Kokomen E, Konodo K, Mortimer JA, Recca WA (1991). Alcohol and tobacco consumption as risk factors for Alzheimer's disease: a collaborative re-analysis of case-control studies. Int. J. Epidemiol., 20(Suppl2): S48-S57.

Gupta PC, Pindborg JJ, Mehta FS (1982). Comparison of carcinogenicity of betel quid with and without tobacco: An epidemiological review. Ecol. Dis., 1: 213-219.

Gupta PC, Ray CS (2003). Smokeless tobacco and health in India and South Asia. Respirol., 8: 419-431.

IARC (1985). Monographs on the evaluation of the carcinogenic risk of chemicals to humans, Tobacco habits other than smoking: Betel-quid and areca-nut chewing and some related nitrosamines. Int. Agency for Res. Cancer Lyon, 37: 141-200.

Jafarey NA, Zaidi SH (1987). Cancer in Pakistan. J. Pakist. Med. Ass., 37: 178-183.

Jayant K, Deo MG (1986). Oral cancer and cultural practices in relation to betel quid and tobacco chewing and smoking. Cancer Detect. Prev., 9: 207-213.

John RM (2005). Tobacco consumption patterns and its health implications in india, Health policy, 71: 213-22.
Langdon JD and Partridge M (1992). Expression of the tumoursuppressor gene p53 in oral cancer. Brit. J. Oral maxillofac. Surg., 30: 214-220.

Mack TM (2001). The new pan-Asian paan problem. Lancet, 357: 16381639.

Merchant A, Husain SS, Hosain (2000). Paan without tobacco: an independent risk factor for oral cancer. Int. J. Cancer, 86: 128-131.

Negri E, La Vecchia C, Franceschi S, Tavani A (1993). Attributable risk for oral cancer in northern Italy. Cancer Epidemiol. Biomarkers Prev., 2: $189-193$

Ostergaard K (1977). The concentration and cadmium in renal tissue from smokers and nonsmokers. Acta Med. Scand., 202: 193-195.

Qayum A (2004). Isolated preparations. Guidelines and instructions. In Fundamentals of Experimental Pharmacology, (1st.edn.) New Awan Printers: Peshawar, 4: 01-4, 16.

Sofowora EA (1993). Phytochemical Assays. In "Medicinal Plants and Traditional Medicine in Africa". 3rd Edition, Spectrum Books Limited Nigeria, pp. 150- 153.

U.S Department of Health and Human Services (2001). Women and Smoking: A report of the Surgeon General.

Van Duijn CM, Hofman A (1991). Relation between nicotine intake and Alzheimer's disease. Br. Med. J., 302: 1491-1494.

Warnakulasuriya S, Sutherland G, Scully C (2005). Tobacco, oral cancer, and treatment of dependence. Oral Oncol., 41: 244-260.

World Health Organization (2000). Addressing the Worldwide Tobacco Epidemic through Effective Evidence-Based Treatment. Expert Meeting March 1999, Rochester, Minnesota, USA. In Tobacco Free Initiative. 